\title{
IMPACTS ON VEGETATION AFTER SELECTIVE CUTTING IN FOREST CONCESSION AREA IN THE SOUTHWESTERN BRAZILIAN AMAZON
}

\author{
Raquel Helena Felberg Jacobsen', Marta Silvana Volpato Sccoti2*, Suelen Thaina Silva Fagundes ${ }^{3}$, \\ João Fideles de Brito Junior ${ }^{1}$, Scheila Cristina Biazatti ${ }^{3}$ \\ ${ }^{1}$ Universidade Federal de Rondônia. Programa de Pós-Graduação em Ciências Ambientais, Rolim de Moura, Rondônia, Brasil. Email: \\ helenafelberg@gmail.com, britojf.ro@gmail.com \\ 2*Universidade Federal de Rondônia, Departamento de Engenharia Florestal, Programa de Pós-graduação em Ciências Ambientais. Rolim de \\ Moura, Rondônia, Brasil. E-mail: martasccoti@unir.br. \\ ${ }^{3}$ Universidade Federal de Rondônia, Departamento de Engenharia Florestal. Rolim de Moura, Rondônia, Brasil. E-mail: \\ scheilacristinabiazatti@gmail.com, taynanfag@hotmail.com \\ Received for publication: 28/03/2019 - Accepted for publication: 27/04/2020
}

\begin{abstract}
Resumo
Impactos na vegetação após corte seletivo em área de concessão florestal na Amazônia sul-ocidental brasileira. O monitoramento da floresta após as atividades de exploração representa uma ferramenta importante para a gestão florestal, auxiliando no planejamento de uso dos recursos florestais. A presente pesquisa teve por objetivo avaliar os impactos na vegetação arbórea após um ano do término da exploração florestal em área de concessão na Floresta Nacional do Jamari, RO. A vegetação foi avaliada antes da exploração e após a exploração em uma Unidade de Produção Anual (UPA) com taxa de corte de $14,14 \mathrm{~m}^{3}$.ha ${ }^{-1}$. Delimitaram-se sete parcelas permanentes de 0,5 ha, distribuídas aleatoriamente, onde avaliou-se todos os indivíduos com Diâmetro Altura do Peito (DAP) $\geq 10 \mathrm{~cm}$. A avaliação dos impactos baseou-se em dois critérios, a diversidade e a estrutura da vegetação (fitossociológica, paramétrica, diamétrica e interna). Houve redução de $2 \%$ na densidade de plantas e perda de 2 espécies. O estoque volumétrico diminuiu nas classes acima de $80 \mathrm{~cm}$ de DAP e a estrutura diamétrica manteve o maior estoque de plantas nas menores classes. As atividades de exploração colaboraram em 3,57 \% para aumento da taxa de mortalidade, além de causar danos leves e severos em 15 ind.ha $^{-1}$. A qualidade do fuste foi, predominantemente, fuste reto $(82,36 \%)$. Os danos observados estão dentro dos limites esperado para áreas com baixa taxa de corte e submetidas às técnicas de exploração de impacto reduzido. Sugere-se a continuidade do monitoramento a médio e longo prazo afim de descrever os padrões de regeneração e o crescimento das espécies, principalmente as madeireiras, projetando os estoques futuros de corte.

Palavras-chave: Manejo em florestas naturais; Dinâmica florestal; Concessão florestal.
\end{abstract}

\begin{abstract}
The forest monitoring after exploration activities is an important tool for forest management, helping to plan the use of forest resources. This research aimed to evaluate the impacts on tree vegetation after one year of the end of forest harvesting in concession area in the Jamari National Forest, RO. The vegetation was evaluated before and after the exploitation in an Annual Production Unit (APU) with cutting rate of $14.14 \mathrm{~m}^{3} \mathrm{ha}^{-1}$. In total, seven permanent plots of 0.5 ha were divided and randomly distributed, where all individuals with diameter at breast height $(\mathrm{DBH}) \geq 10 \mathrm{~cm}$ were evaluated. Impact evaluation was based on two criteria, the diversity and structure of vegetation (phytosociological, parametric, diametric, and internal). There was a reduction of $2 \%$ in plant density and loss of two species. The volumetric supply decreased in the classes above $80 \mathrm{~cm}$ of DBH and the diametric structure maintained the largest supply of plants in the lower classes. The exploration activities collaborated in $3.57 \%$ to increase the mortality rate, besides causing slight and severe damages in 15 ind.ha $^{-1}$. The quality of the stem was predominantly straight $(82.36 \%)$. The damage observed is within the expected limits for areas with low cut rates and subjected to reduced impact exploration techniques. We suggest the continuous monitoring in the medium- and long- term in order to describe the patterns of regeneration and growth of species, mainly logging, projecting the future supply of cutting.

Keywords: Management in natural forests; Forest dynamics; Forest concession.
\end{abstract}

\section{INTRODUCTION}

The main causes of forest cover loss in the Amazon over the years have been associated, mainly with the opening of federal roads, implementation of settlements, hydroelectric and mining projects, illegal exploitation of high commercial value species, and opening of areas for agricultural activities (VALERIANO et al., 2012).

Thus, the Brazilian government has implemented conservation policies in order to promote the use and protection of natural resources, such as the National System of Nature Conservation Unit (SNUC), which establishes criteria and regulations for creation, implementation, and management of conservation units and the Public Forest Management Regulation, Law No. 11,284/2006, which provides for a management model in which

FLORESTA, Curitiba, PR, v. 50, n. 4, p. 1778 - 1787, out/dez 2020.

Jacobsen, R. H. F. et.al.

ISSN eletrônico 1982-4688

DOI: 10.5380/rf.v50 i4. 65680 
the government can grant companies and communities the right to manage Conservation Units (CU) for sustainable use, exploiting timber and non-timber resources (BRASIL, 2006).

In this scenario, Rondônia was the first Brazilian state to bid and to approve the concession of forests by the Brazilian Forest Service (SFB) in 2007 in the Jamari National Forest. National Forests are conservation units of sustainable use, with forest cover of predominantly native species and they have as basic objective the multiple use of forest resources and scientific research, with emphasis on methods for sustainable exploitation of native forests (BRASIL, 2000).

In the bidding process, subordinate companies pay for using products and services, and they are subject to meet a series of requirements to the agencies responsible for inspection at the federal and state levels to ensure the sustainable use of natural resources. Thus, the company that won the bid receives the right to practice sustainable forest management for the exploitation of products and services in forest units for periods ranging between 25 and 30 years, applying less harmful practices of exploitation that maintain the forest dynamics after the exploitation of its resources (BRASIL, 2006).

In this sense, because this is a recent process of public forests use, there are few studies assessing the effects of corporate forest management. Some studies addressing conservation units are cited, but focused on an experimental scale (HIGUCHI et al., 2010).

Thus, environmental impacts are understood as any change in physical, chemical, and biological properties of the environment, caused by any human action, directly or indirectly, which may affect the health, safety and well-being of the population, social and economic activities, biome, aesthetic, and sanitary conditions of the environment and the quality of environmental resources (BRASIL, 1986).

According to Souza and Soares (2013) in the evaluation of the post-exploitation impacts, it is necessary to observe the influence of management on richness, composition, structure, and dynamics of the forest and these responses, after exploitation, it can be used as practical information that will assist public and private entities in the management of forests and, consequently, in the elaboration of sustainable forest management plans. Thus, this work aims to evaluate the effect on tree vegetation one year after the end of forest exploitation activities, in a concession area in the Jamari National Forest, Rondônia State (RO).

\section{MATERIAL AND METHODS}

\section{LOCATION AND CHARACTERIZATION OF THE STUDY AREA}

The study was carried out in an Annual Production Unit (UPA 5) with 1,926.7 ha, located in Forest Management Unit III (UMF III), in Flona Jamari, RO (coordinates $09^{\circ} 00^{\prime} 00^{\prime \prime}$ to $09^{\circ} 30^{\prime} 00^{\prime \prime} \mathrm{S}$ and $62^{\circ} 44^{\prime} 05^{\prime \prime}$ to $63^{\circ} 16^{\prime} 54^{\prime \prime}$ W). UPA 5 was explored between April and November 2015 at a cutoff rate of $14.14 \mathrm{~m}^{3} \mathrm{ha}^{-1}(3,042$ tree.ha- $\left.{ }^{-1}\right)$.

The region has a climate classified as Tropical Monsoon (Am), hot and humid, with an annual rainfall average of $2300 \mathrm{~mm}_{\text {.year }}^{-1}$ and an average annual temperature of $26{ }^{\circ} \mathrm{C}$ (ALVARES et al., 2013). The natural vegetation of the region is composed predominantly of Cloud Forest. The relief varies from gently wavy to flat. Latosols and Acrisol are broadly found, with emphasis on occurrence for Red-Yellow Dystrophic Acrisol (MMA, 2005).

\section{Data collection}

Data were collected with two forest inventories, which were performed before and after the exploitation activities. In March 2015, seven permanent sampling units were marked and inventoried, with dimensions of 0.5 ha. The sampling units were randomly distributed and subdivided into units of $10 \times 10 \mathrm{~m}$, following the methodology described in the guidelines for marking and measuring permanent plots in the Amazon Biome (SILVA et al., 2005). This guideline suggests marking a sampling unit of 0.25 ha for every 250 ha of managed area when the UPA has an area greater than 1000 ha.

Within the sample units, all individuals with diameter at breast height $(\mathrm{DBH}) \geq 10 \mathrm{~cm}$ were measured and properly numbered with an aluminum platelet. In addition to $\mathrm{DBH}$, a stem identification class (straight, tortuous, inclined, incomplete $(\geq 4.0 \mathrm{~m})$, incomplete $(<4.0 \mathrm{~m})$ ) was also collected. Each tree was marked with red ink, at the $\mathrm{DBH}$ point, to assist in further re-evaluation.

One year after the end of the exploitation activities, the plots were re-evaluated, assessing all individuals sampled in 2015, plus those who entered in the period.

In this evaluation, in addition to the DBH and the stem quality identification class, the presence of damage (cause, intensity, and position of the damage (SILVA et al., 2005) was also evaluated. The botanical identification was carried out by consultation with the specialist professional granted by the concessionaire company, taxonomists of the Emílio Goeldi Museum, bibliographies (LORENZI, 2002a, 2002b) and specific sites of the area (Flora do Brasil 2020 and Flora brasiliensis). The classification system adopted was APG III. 


\section{Data analysis}

The maintenance of the integrity of the forest ecosystem, one year after the end of exploitation activities, was evaluated based on two main criteria: effects on the composition of species and effects on tree vegetation structure.

The evaluation of the effects of selective exploitation on the composition of the areas was assesses by the results of floristic richness, Shannon diversity index $\left(\mathrm{H}^{\prime}\right)$ and Pielou's evenness index (J) (SOUZA and SOARES, 2013). Estimation of the values of the Shannon's and Pielou's indices were generated discarding 255 individuals that were not completely identified.

The effects caused on the structure of the trees were assessed by the results of horizontal or phytosociological structure (density, frequency, dominance, and importance value), parametric structure (supply by DBH class), internal structure (represented by the quality and damage of the stem), mortality and ingress (SOUZA and SOARES, 2013).

The volume of commercial wood of each tree in the sample was estimated to generate the parametric structure and then the volume was grouped by diameter class and transformed per hectare. The individual volume was estimated by the equation of single-entry volume, adjusted for the species exploited in the study area (AMATA, 2014) (Equation 1). Intervals of 10 in $10 \mathrm{~cm}$ were considered.

$V_{c / c}=0.9494-0.0053 * D A P+0.00086 * D A P^{2}$ (Equation 1).

Where: $\mathrm{V}_{\mathrm{c} / \mathrm{c}}=$ volume with bark in $\mathrm{m}^{3} ; \mathrm{DBH}=$ diameter at breast height $(1.30 \mathrm{~m})$ in $\mathrm{cm}$;

\section{Statistical analysis}

The results obtained from the floristic and structural surveys of the forest, before and after exploitation, were submitted to Lilliefors test and Cochran's and Barllet's homoscedasticity. Based on these assumptions, the Student $t$-test was performed, at a 5\% probability level, to verify the existence of significant differences between the means of the absolute density (AD), absolute dominance (ADo) and estimated volume (V) relating the year before the exploitation with the year after it.

The analyses and values of the Shannon's and Pielou's indices, as well as the DA, ADo, absolute frequency (AF), and importance value (IV) parameters were obtained with the R CORE TEAM statistical program (2019), using the Agricolae package for statistical tests and the Phyto R for phytosociological structure.

\section{RESULTS}

One year after the end of the exploitation activities, a $2 \%$ reduction in the total density of individuals with $\mathrm{DBH} \geq 10 \mathrm{~cm}$ was observed, from 464.28 ind.ha $^{-1}$ to 454.86 ind.ha $^{-1}$ and the disappearance of two genera and two species, however, the number of families was the same (Table 1).

When analyzing the average values of $\mathrm{AD}, \mathrm{ADo}$ and estimated volume before and after exploration, it was observed that the differences between the means were not significant ( $p>0.05)$, thus, note that the total forest supply before and after the exploitation were similar (Table 1).

Table 1. Richness, diversity and middle value of forest of stocks before and after one year the end of logging activities in Annual Production Unit, Flona of Jamari, RO.

Tabela 1. Riqueza, diversidade e valores médios de estoques da floresta antes e após um ano do término das atividade de exploração madeireira em Unidade de Produção Anual, na Flona do Jamari, RO.

\begin{tabular}{ccccc}
\hline $\begin{array}{c}\text { Evaluated } \\
\text { characteristics }\end{array}$ & Forest before exploitation & Forest after exploitation & T-test. \\
\hline Number of families & 33 & 33 & - \\
\hline Number of genera & 102 & 100 & - \\
\hline Number of species & 142 & 140 & - \\
\hline $\mathrm{H}^{*}$ & 3.800 & 3.798 & - \\
\hline $\mathrm{J}^{*}$ & 0.774 & 0.775 & $(\mathrm{p}>0.05)$ \\
\hline $\mathrm{AD}\left(\right.$ ind.ha $\left.^{-1}\right)$ & 464.28 & 454.86 & $(\mathrm{p}>0.05)$ \\
\hline $\mathrm{ADo}\left(\mathrm{m}^{2}\right.$ ha $\left.^{-1}\right)$ & 23.5040 & 21.8759 & $(\mathrm{p}>0.05)$ \\
\hline $\mathrm{Vc} / \mathrm{c}\left(\mathrm{m}^{3} \cdot \mathrm{ha}^{-1}\right)$ & 645.84 & 620.5917 & .
\end{tabular}

*Values obtained disregarding unidentified species; Da: absolute density; DoA: absolute dominance and Vc/c: estimated average volume with bark.

FLORESTA, Curitiba, PR, v. 50, n. 4, p. 1778 - 1787, out/dez 2020.

Jacobsen, R. H. F. et.al.

ISSN eletrônico 1982-4688

DOI: 10.5380/rf.v50 i4. 65680 
The 10 species with the SV also maintained their position in the forest structure after the exploitation. Protium robustum was the species with the highest SI before and after exploitation, followed by Pseudolmedia spp., Sclerolobium spp., Eschweilera pseudodecolorans, and Pouteria torta, , they are being highlighted especially by their higher values of density and frequency in all plots studied (Table 2).

Table 2. Phytosociological structure of the main ten species before and after one year the end of logging activities in Annual Production Unit, Flona of Jamari, RO.

Tabela 2. Estrutura fitossociológica das dez principais espécies, antes e após um ano do término das atividades de exploração madeireira, em unidade de produção anual, na Flona do Jamari/RO.

\begin{tabular}{|c|c|c|c|c|c|c|c|c|}
\hline \multirow{2}{*}{ Species } & \multicolumn{4}{|c|}{ Before exploitation } & \multicolumn{4}{|c|}{ After exploitation } \\
\hline & $\mathrm{AD}$ & $\mathrm{AF}$ & ADo & IV & $\mathrm{AD}$ & $\mathrm{AF}$ & ADo & IV \\
\hline $\begin{array}{l}\text { Protium robustum (Swart) } \\
\text { D.M. Porter }\end{array}$ & 49.7 & 100 & 1.93 & 20.66 & 48.6 & 100 & 1.87 & 20.94 \\
\hline Pseudolmedia spp. & 40 & 100 & 1.29 & 15.81 & 38 & 100 & 1.25 & 15.8 \\
\hline Sclerolobium spp. & 23.7 & 100 & 1.46 & 13.07 & 22.9 & 100 & 1.4 & 13.13 \\
\hline $\begin{array}{l}\text { Eschweilera } \\
\text { pseudodecolorans S.A. Mori }\end{array}$ & 24.6 & 100 & 0.85 & 10.64 & 24.9 & 100 & 0.88 & 11.24 \\
\hline Pouteria torta (Mart.) Radlk. & 26 & 100 & 0.72 & 10.37 & 24.6 & 100 & 0.66 & 10.17 \\
\hline $\begin{array}{l}\text { Beilschmiedia brasiliensis } \\
\text { (Kosterm.) Kosterm. }\end{array}$ & 21.1 & 100 & 0.66 & 9.1 & 20.6 & 100 & 0.67 & 9.31 \\
\hline Peltogyne paniculata Benth. & 11.1 & 100 & 1.19 & 9.17 & 10.9 & 100 & 1.06 & 8.95 \\
\hline $\begin{array}{l}\text { Huberodendron swietenioides } \\
\text { (Gleason) Ducke }\end{array}$ & 8.3 & 71.43 & 0.79 & 6.38 & 7.4 & 71.43 & 0.78 & 6.45 \\
\hline Copaifera multijuga Hayne & 6 & 85.71 & 0.73 & 5.9 & 6.3 & 85.71 & 0.75 & 6.31 \\
\hline Apeiba echinata Gaertn. & 5.4 & 100 & 0.42 & 4.69 & 5.4 & 100 & 0.43 & 4.9 \\
\hline
\end{tabular}

Where: $\mathrm{AD}$ : absolute density (ind.ha $\left.{ }^{-1}\right) ; \mathrm{AF}:$ absolute frequency (\%); ADo: absolute dominance $\mathrm{m}^{2}$ ha $^{-1}$; IV: importance value (\%).

The families with the greatest richness remained. However, two species were lost after the exploitation activities: Faramea crassifolia (Rubiaceae) and Laetia procera (Salicaceae).

However, when analysing the structure of the species used in forest exploitation, there is a change in the order of importance of the main species, where before exploration were the five most important species in descending order were Peltogyne paniculata, Dinizia excelsa, Astronium lecointei Couratari stellata and Hymenolobium heterocarpum and, after forest harvesting, Peltogyne paniculata, Astronium lecointei and Couratari stellata were maintained. Erisma cf. bicolor and Qualea paraensis began to occupy the fourth and fifth position of higher IV, respectively (Table 3).

Table 3. Phytosociological structure before and after one year of logging activities, based on harvested species, in annual production unit, Flona of Jamari, RO.

Table 3. Phytosociological structure before and after one year the end of species splored logging activities of in annual production unit, Flona of Jamari, RO.

\begin{tabular}{lllllllll}
\hline \multirow{2}{*}{ Species } & \multicolumn{3}{c}{ Before exploitation } & \multicolumn{5}{c}{ After exploitation } \\
\cline { 2 - 10 } & AD & AF & ADo & IV & AD & AF & ADo & IV \\
\hline Peltogyne paniculata Benth. & 11.1 & 100 & 1.19 & 9.17 & 10.9 & 100 & 1.06 & 8.95 \\
\hline Astronium lecointei Ducke & 4.9 & 100 & 0.34 & 4.22 & 4.3 & 100 & 0.32 & 4.13 \\
\hline Couratari stellata A. C. Sm. & 4.6 & 100 & 0.3 & 3.99 & 3.7 & 85.71 & 0.26 & 3.48 \\
\hline Erisma cf. bicolor Ducke & 2.3 & 85.71 & 0.3 & 3.25 & 2.3 & 85.71 & 0.31 & 3.42 \\
\hline Qualea paraensis Ducke & 3.4 & 71.43 & 0.29 & 3.22 & 3.1 & 71.43 & 0.3 & 3.3 \\
\hline Clarisia racemosa Ruíz \& Pav. & 4 & 85.71 & 0.23 & 3.31 & 3.4 & 85.71 & 0.22 & 3.25 \\
\hline Diplotropis rodriguesii H.C. Lima & 3.4 & 85.71 & 0.24 & 3.23 & 3.1 & 71.43 & 0.24 & 3.03 \\
\hline Dinizia excelsa Ducke & 3.7 & 71.43 & 1.38 & 7.92 & 2.9 & 57.14 & 0.3 & 2.99 \\
\hline Brosimum rubescens Taub. & 4 & 71.43 & 0.17 & 2.8 & 4 & 71.43 & 0.17 & 2.9 \\
\hline
\end{tabular}

FLORESTA, Curitiba, PR, v. 50, n. 4, p. 1778 - 1787, out/dez 2020.

Jacobsen, R. H. F. et.al.

ISSN eletrônico 1982-4688

DOI: 10.5380/rf.v50 i4. 65680 


\begin{tabular}{lllllllll}
\hline Erisma fuscum Ducke & 2.3 & 85.71 & 0.18 & 2.75 & 2.3 & 85.71 & 0.19 & 2.89 \\
\hline Goupia glabra Aubl & 0.6 & 28.57 & 0.37 & 2.17 & 0.6 & 28.57 & 0.4 & 2.46 \\
\hline Hymenolobium heterocarpum Ducke & 2.6 & 85.71 & 0.35 & 3.54 & 2.3 & 71.43 & 0.14 & 2.41 \\
\hline Caryocar glabrum Pers. & 1.4 & 71.43 & 0.23 & 2.53 & 1.1 & 57.14 & 0.15 & 1.94 \\
\hline Pouteria guianensis Aubl. & 1.4 & 57.14 & 0.07 & 1.59 & 1.4 & 57.14 & 0.07 & 1.64 \\
\hline Cariniana micrantha Ducke & 1.4 & 57.14 & 0.06 & 1.57 & 1.4 & 57.14 & 0.06 & 1.61 \\
\hline Tabebuia incana A.H. Gentry & 0.9 & 42.86 & 0.02 & 1 & 1.1 & 57.14 & 0.02 & 1.34 \\
\hline Bowdichia nitida Spruce ex Benth. & 1.1 & 42.86 & 0.07 & 1.28 & 1.1 & 42.86 & 0.07 & 1.32 \\
\hline Mezilaurus itauba (Meisn.) Taub. ex Mez. & 0.9 & 42.86 & 0.05 & 1.16 & 0.9 & 42.86 & 0.06 & 1.2 \\
\hline Dipteryx odorata (Aublet) Willd. & 0.6 & 28.57 & 0.09 & 1 & 0.6 & 28.57 & 0.09 & 1.03 \\
\hline Simarouba amara Aubl. & 0.6 & 14.29 & 0.11 & 0.82 & 0.6 & 14.29 & 0.11 & 0.86 \\
\hline $\begin{array}{l}\text { Peltogyne venosa subsp. densiflora } \text { Spruce ex. } \\
\text { Benth }\end{array}$ & 0.3 & 14.29 & 0.01 & 0.74 & 0.3 & 14.29 & 0.01 & 0.74 \\
\hline Cedrela fissilis Vell. & 0.3 & 14.29 & 0.09 & 0.71 & 0.3 & 14.29 & 0.09 & 0.74 \\
\hline Caryocar villosum (Aubl.) Pers. & 0.6 & 28.57 & 0.03 & 0.73 & 0.3 & 14.29 & 0.02 & 0.42 \\
\hline Weid:
\end{tabular}

Where: AD: absolute density (ind.ha $\left.{ }^{-1}\right)$; AF: absolute frequency (\%); ADo: absolute dominance $\mathrm{m}^{2}$.ha ${ }^{-1}$; IV: importance value (\%).

Regarding parametric structure, we found that the AD (ind.ha-1) by diametric class post-logging showed significant changes, while the variables basal area $\left(\mathrm{m}^{2} \cdot \mathrm{ha}^{-1}\right)$ and volume $\left(\mathrm{m}^{3} \mathrm{ha}^{-1}\right)$, generally presented reduction, especially in classes above $80 \mathrm{~cm}$ (Table 4). It was verified that, via density, the inverted "J" distribution was maintained, with a higher concentration of individuals in lower classes.

Table 4. Parametric structure, by diameter group, before and after one year the end of logging activities in Annual Production Unit, Flona of Jamari, RO.

Tabela 4. Estrutura paramétrica por classes de diâmetro observada antes e após um ano do término das atividades de exploração madeireira em Unidade de Produção Anual, na Flona Jamari, RO.

\begin{tabular}{c|c|c|c|c|c|c}
\hline \multirow{2}{*}{ DBH class (cm) } & \multicolumn{2}{|c|}{ AD (ind.ha-1) } & \multicolumn{2}{c|}{ ADo $\left(\mathrm{m}^{2} . \mathrm{h}^{-1}\right)$} & \multicolumn{2}{c}{ Vc/c $\left(\mathrm{m}^{3} . \mathrm{h}^{-1}\right)$} \\
\cline { 2 - 7 } & Before & After & Before & After & Before & After \\
\hline $10-20$ & 297.1 & 294.0 & 4.746 & 4.742 & 312.0 & 309.1 \\
\hline $20-30$ & 88.9 & 85.1 & 4.129 & 3.966 & 118.2 & 113.3 \\
\hline $30-40$ & 36.9 & 35.7 & 3.425 & 3.363 & 65.8 & 64.2 \\
\hline $40-50$ & 20.9 & 20.3 & 3.294 & 3.213 & 50.9 & 49.6 \\
\hline $50-60$ & 10.6 & 10.9 & 2.401 & 2.457 & 33.3 & 34.1 \\
\hline $60-70$ & 4.9 & 5.1 & 1.601 & 1.695 & 20.5 & 21.7 \\
\hline $70-80$ & 2.0 & 2.0 & 0.868 & 0.887 & 10.6 & 10.8 \\
\hline $80-90$ & 1.1 & 0.6 & 0.652 & 0.327 & 7.7 & 3.9 \\
\hline $90-100$ & 0.6 & 0.6 & 0.419 & 0.394 & 4.8 & 4.6 \\
\hline$>100$ & 1.4 & 0.9 & 1.971 & 0.926 & 21.9 & 10.4 \\
\hline Total & 464.3 & 455.1 & 23.504 & 21.970 & 645.8 & 621.8 \\
\hline
\end{tabular}

Where: AD: Absolute density in individuals per $\mathrm{h}$ ind.ha ${ }^{-1}$; ADo: Absolute dominance in $\mathrm{m}^{2} \mathrm{ha}^{-1}$ and $\mathrm{Vc} / \mathrm{c}$ : Volume with bark in $\mathrm{m}^{3} \mathrm{ha}^{-1}$.

Out of the 100 dead individuals sampled in the seven plots ( 28.57 ind.ha $^{-1)}, 42$ died of natural factors (12 ind.ha ${ }^{-1)}$ and 58 of forest management operations (16.57 ind.ha ${ }^{-1}$ ), corresponding to $2.58 \%$ and $3.57 \%$ of the mortality rate, respectively. The size class with the highest number of dead individuals was Class I $(10 \mathrm{~cm} \leq \mathrm{DBH}$ $<20 \mathrm{~cm}$ ). The species with the highest number of dead individuals, who had complete identification, were Protium robustum and Sclerolobium spp. with nine individuals each and Pouteria torta with eight. Note that 33 plants that died in the period did not have the identification completed.

FLORESTA, Curitiba, PR, v. 50, n. 4, p. 1778 - 1787, out/dez 2020.

Jacobsen, R. H. F. et.al.

ISSN eletrônico 1982-4688 
The ingress rate was $4.3 \%$, in Class I $(10 \mathrm{~cm} \leq \mathrm{DBH}<20 \mathrm{~cm})$. The species with the highest number of ingressing individuals were Sclerolobium spp. (six individuals), Protium robustum (five individuals), Tachigali chrysophylla, and Virola spp. (four individuals).

The damage analysis of the internal structure of the forest indicated that 31.57 ind.ha $^{-1}$ were affected by the exploitation. Out of these, 15.15 ind.ha ${ }^{-1}$ presented some type of damage and 16.57 ind.ha $^{-1}$ were killed. For damage due to natural causes, 22.86 ind.ha $^{-1}$ were recorded (Table 5).

Table 5. Damage causes (DC) and damage intensity (DI) observed in tree vegetation after a year of the end of the activities of forest exploration in Annual Production Unit, Flona Jamari, RO.

Tabela 2. Causa (CD) e Intensidades de danos (ID) observados na vegetação arbórea após um ano do término das atividades de exploração florestal em Unidade de Produção Anual, na Flona Jamari, RO.

\begin{tabular}{c|c|c|c|c}
\hline DC/DI & Mild (ind.ha $\left.{ }^{-1}\right)$ & Severe $\left(\right.$ ind.ha $\left.^{-1}\right)$ & Dead (ind.ha $\left.^{-1}\right)$ & Total \\
\hline Natural damage & 6.00 & 16.86 & - & 22.86 \\
\hline Exploitation-related damage & 7.43 & 7.72 & - & 15.15 \\
\hline Dead after exploitation & - & - & 16.57 & 16.57 \\
\hline Natural Death & - & - & 12.00 & 12.00 \\
\hline Total & 13.43 & 24.58 & 28.57 & 66.58 \\
\hline$\%$ & 20.2 & 36.9 & 42.9 & 100 \\
\hline
\end{tabular}

Regarding the place of damage caused by management operations, a higher number of individuals with damaged stem was observed, followed by the crown and damaged crown and stem. For natural damage, the highest proportion of damage was observed in the crown and trunk (Table 6).

Table 6. Damage cause (DC) and position of damage (PD) observed in tree vegetation after a year of the end of the activities of forest exploration in Annual Production Unit, Flona Jamari, RO.

Tabela 3. Causa (CD) e Posições de danos (PD) observados na vegetação arbórea após um ano do término das atividades de exploração florestal em Unidade de Produção Anual, Flona Jamari, RO.

\begin{tabular}{c|c|c|c|c|c}
\hline DC/PD & $\begin{array}{c}\text { Crown } \\
\left(\text { ind.ha }^{-1}\right)\end{array}$ & $\begin{array}{c}\text { Stem } \\
\left(\text { ind.ha }^{-1}\right)\end{array}$ & $\begin{array}{c}\text { Crown and stem } \\
\left(\text { ind.ha }^{-1}\right)\end{array}$ & $\begin{array}{c}\text { Dead } \\
\left(\text { ind.ha }^{-1}\right)\end{array}$ & $\begin{array}{c}\text { Overall Total } \\
\left(\text { ind.ha }^{-1}\right)\end{array}$ \\
\hline Natural damage & 15.43 & 7.43 & - & - & 22.86 \\
\hline Exploitation-related damage & 6.29 & 8.00 & 0.86 & - & 15.15 \\
\hline Dead after exploitation & - & - & - & 16.57 & 16.57 \\
\hline Natural Death & - & - & - & 12.00 & 12.00 \\
\hline Total & 21.72 & 15.43 & 0.86 & 28.57 & 66.58 \\
\hline
\end{tabular}

Regarding the quality of the stem of the remaining individuals in the forest, a predominance of straight stem was observed, with $82.36 \%$ of the total density, and individuals with tortuous and, or inclined and, or incomplete, were $17.64 \%$. Considering the commercial value species, explored in the UPA, $10.23 \%$ presented straight stem and $1.32 \%$ with some bent and, or inclination, and or incomplete stem (Table 7).

Table 7. Quality of the stem of the remaining individuals after one year of the end of the forestry activities in the Production Unit at Flona Jamari, RO.

Tabela 4. Qualidade do fuste dos indivíduos remanescentes após um ano do término das atividades de exploração florestal em Unidade de Produção na Flona Jamari, RO.

\begin{tabular}{|c|c|c|c|c|c|}
\hline \multirow{2}{*}{ Quality of the stem } & \multicolumn{2}{|c|}{ Unexploited species } & \multicolumn{2}{|c|}{ Exploited species } & \multirow{2}{*}{ Total $\%$} \\
\hline & AD (ind.ha $\left.{ }^{-1}\right)$ & $\%$ & AD (ind.ha ${ }^{-1}$ ) & $\%$ & \\
\hline Straight & 328.29 & 72.13 & 46.57 & 10.23 & 82.36 \\
\hline Bent & 48.86 & 10.73 & 3.43 & 0.75 & 11.49 \\
\hline Inclined & 8.57 & 1.88 & 1.14 & 0.25 & 2.13 \\
\hline Incomplete $\geq 4 \mathrm{~m}$ & 13.71 & 3.01 & 1.14 & 0.25 & 3.26 \\
\hline Incomplete < $4 \mathrm{~m}$ & 3.14 & 0.69 & 0.29 & 0.06 & 0.75 \\
\hline Overall Total & 402.57 & 88.45 & 52.57 & 11.55 & 100.0 \\
\hline
\end{tabular}

FLORESTA, Curitiba, PR, v. 50, n. 4, p. 1778 - 1787, out/dez 2020.

Jacobsen, R. H. F. et.al.

ISSN eletrônico 1982-4688

DOI: 10.5380/rf.v50 i4. 65680 


\section{DISCUSSION}

As observed in this study, there were no significant differences for the density of tree individuals per hectare, after exploitation activities in UPA 5, in Flona do Jamari. Souza et al. (2017) verified a similar short-term scenario in a management area in dense Cloud Forest submitted to a exploitation rate of $20.02 \mathrm{~m}^{3} . \mathrm{ha}^{-1}$, in the state of Amazonas.

As a consequence of the small reduction in the number of individuals after activities, changes in forest richness were found only at the level of genus and species, that is, two species and two genera were eliminated. However, these changes did not affect the diversity indices, which showed the same trend before and after exploitation. This scenario was also observed by Lima et al. (2018) in an exploitation area at Flona do Tapajós, one year after harvesting.

These results are significant indicators for the evaluation of policies for the use of forest resources and quality control of forest management, especially in forest concessions, which deal with the use of resources in public forests, where management cannot compromise the quality and efficiency of environmental services, because higher preserved biodiversity in the country are found mostly in Conservation Units.

Thus, the regulation is clear regarding the preservation of forest resources and when they are not fulfilled can lead to the termination of the concession (Brasil, 2006). In this sense, the techniques adopted by the concessionaire for the removal of wood in the area caused few changes in the composition and structure of the analyzed vegetation. There was only a small reduction in density, dominance, and volume, which is expected since the supply undergoes changes due to harvest and mortality. In the area, the low harvest rate adopted $\left(14.14 \mathrm{~m}^{3} . \mathrm{ha}^{-}\right.$ ${ }^{1)}$ and the use of reduced effect exploitation techniques, such as opening of fishbone-shaped extensions, directed cutting, among others, contributed to the lower effect on the remaining vegetation.

The species that were lost after exploitation presented only one sampled individual, indicating that groups of species with low density are the most susceptible to exploitation practices.

In this sense, it is highlighted that the concern regarding the exploitation impacts should not only be applied with species that present commercial value, but also the behavior of rare species and other groups of nonarboreal plants, because the integrity of the managed forest must be maintained, as well as its ecosystem. As an example, we mention the work carried out by Magrach et al. (2016) who observed, in a forest concession area in Malaysia, the influence of selective cutting on species interaction networks. In this study, the authors observed a significant increase in the composition and density of liana species in exploited areas, which affected the growth rates of the remaining forest.

The species with the highest importance value (Protium robustum,Pseudolmedia spp, Sclerolobium spp., Eschweilera pseudodecolorans, and Pouteria torta) presented few changes in structure after exploitation. These species, although not characterized as a commercial interest in the region, play an important ecological role in the ecosystem, such as Protium robustum (Breu), which widely occur in the Amazon region and presents intense fruiting, serving as food to the fauna (LORENZI, 2002a).

Vieira et al. (2015) analyzing the structure and multiple use of tree species in managed forests, in an area of Dense Cloud Forestin Pará, at a cutting rate of $30 \mathrm{~m}^{3} \mathrm{ha}^{-1}$ concluded that after four years of exploitation, significant differences were identified only in total volume and absolute dominance, factors that can affect the order of importance of the species. This was perceived in our study, for the species explored in UPA 5, even with the evaluation in a short period of time it was observed that D. excelsa and H. heterocarpum, occupied the fourth and fifth place in order of importance, before the exploitation, and they were replaced by Erisma cf. bicolor and Qualea paraenses, after exploitation. This fact reflects the influence of exploratory activities resulting from the harvest of individuals of these species, which reduced their density and dominance, thus affecting the order of importance in the forest.

Therefore, the monitoring of the remaining individuals of the exploited species requires special attention, in order to evaluate the quality of the forest for a second cutting cycle, which in the studied UPA represented a reduction, especially in the classes above $80 \mathrm{~cm}$ of $\mathrm{DBH}$, for density, basal area, and volume, respectively, a class that presented the highest wood removal in the management plan.

Reis et al. (2010) observed, after 28 years of exploitation, that forest biomass after exploration in a management area in Flona do Tapajós was recovered. However, the exploited species still presented a negative balance in their supply suggesting a higher cutting cycle, since the species respond differently to forest exploitation, presenting behavior and differentiated regeneration time. However, it is emphasized that in this study the cutting rate was $75.5 \mathrm{~m}^{3} \cdot \mathrm{ha}^{-1}$, a value above that one value defined in the legal bases of the govern management plans in the Amazon Biome.

In the study area, one year after the end of the exploitation activities, the forest biomass balance presented negative values, reducing the density of plants above $10 \mathrm{~cm}$ of DBH, in the order of 9.09 ind.ha $^{-1}, 1,534 \mathrm{~m}^{2} \mathrm{ha}^{-1}$ of basal area, and $24.04 \mathrm{~m}^{3} \cdot \mathrm{ha}^{-1}$ in wood volume, values triggered by the harvest that increases the mortality rate,

FLORESTA, Curitiba, PR, v. 50, n. 4, p. 1778 - 1787, out/dez 2020. 
exceeding the values of growth and ingress of the forest in the short term. Lima et al. (2018) described that the harvesting effect was the main cause of mortality in the exploration area in Flona do Tapajós one year after the end of the activities, resulting in a negative supply balance.

Generally, in areas of short-term forest exploitation, there is a greater supply outflow, because in addition to harvested wood, the mortality rate intensifies due to the increase in individuals who die from exploitation activities. This scenario was described in UPA 5, since the mortality rate due to causes of exploitation represented $3.57 \%$ of the total number of individuals who died in the period, and the rate was $2.58 \%$ due to natural causes.

However, over time, the mortality rate due to exploitation causes tends to be reduced and ingresses increase, as well as the growth of the remaining species, supported by the opening of clearings (PUIG, 2008), supporting the positive balance in forest biomass. As evidenced by Silva et al. (2005) and Reis et al. (2010) the forest tends to stabilize approximately five years after exploration, with no significant difference between the understory of an intact forest and that of an exploited forest.

Regarding the analysis of the internal structure of the forest after exploitation, it was found that for every 3.04 trees harvested per hectare, 15.15 ind.ha ${ }^{-1}$ presented direct damage caused by the exploitation activities, and the severe damage was considered that affecting more individuals ( 7.71 ind.ha $\left.{ }^{-1}\right)$ and the stem was the most affected by the damage. Veríssimo et al. (2002), analyzing management areas in Paragominas, PA, which were submitted to a cutting rate of $23 \mathrm{~m}^{3} \cdot \mathrm{ha}^{-1}$, observed that for every 6.4 trees harvested per hectare, 150 trees ha $^{-1}$, were severely damaged.

It is also emphasized that 22.86 ind.ha $^{-1}$ had damage recorded by natural causes, out of these 16.86 ind.ha $^{-}$ ${ }^{1}$, were characterized with severe damage, considerable value, when compared to the damage directly arising from the harvesting. In this sense, we emphasize the significance of understanding whether part of this damage may be due to the indirect action of exploitation activities, because the opening of the canopy caused by selective cutting can imbalance other trees that are on the edges of the clearings, favoring their fall, or damaging them, in case of winds and, or more intense rains.

Thus, the use of techniques with reduced impact on exploratory activities, as a way to avoid damage to the forest during forest exploitation activities becomes indispensable to provide greater sustainability to forest management, since the damage directly affects the growth of the remaining trees. Vidal et al. (2002), studying the growth of trees three years after harvesting in Paragominas, PA, observed that trees without damage grew on average $0.72 \mathrm{~cm}$.year ${ }^{-1}$, those with mild damage grew $0.51 \mathrm{~cm}$.year ${ }^{-1}$; those with moderate damage grew $0.47 \mathrm{~cm}$ year-1 and those with severe damage, grew $0.33 \mathrm{~cm}$.year ${ }^{-1}$. Thus, according to the authors, the higher incidence of damage may imply a longer period until a second harvest in the area.

Gatti et al. (2015) comparing the structures and composition of primary forests, selectively exploited forests, and shallow cutting areas in Africa, noted that exploitation can significantly reduce the biomass of a tropical forest for many decades, reducing the capacity of carbon storage above ground, and creating opportunities for aggressive species to establish themselves and to delay ecological succession, which creates uncertainties regarding the sustainability of selective exploitation.

Regarding the quality of the stem, data indicate that the remaining individuals of commercial interesting species showed little contribution to the percentage value of straight stem (10.23\% of the total trees with straight stem). Souza e Souza (2004) performing structural analysis in a Dense Cloud Forest of Terra Firme not explored in the Amazon, found that on average $89 \%$ of the individuals in the forest had good stem quality (80 to $100 \%$ utilization) and out of these $34 \%$ were represented by trees with commercial value. Therefore, it is noticed that despite the considerable percentage of individuals with adequate stem for commercialization, most of them belong to unexplored species, which implies a lower economic potential of the forest.

\section{CONCLUSIONS}

- Short-term forest exploitation activities reduced forest supply, but they did not interfere in floristic composition and species diversity.

- The damage caused to the remaining trees due to the exploitation activities, increased the mortality rate of the forest, occurrence of severe damage and ingress of species with preference to environments with higher incidence of light.

- The management in the conservation unit carried out by the concessionary company proved to be adequate to maintain the quality of the composition, structure, and supplies of the species in the monitored area one year after exploitation, but it is suggested the continuity of monitoring in both medium- and long-term to generate information of the time necessary for complete recovery of damage after harvest, changes in floristic composition, and growth rates of the remaining trees, especially those with commercial value.

FLORESTA, Curitiba, PR, v. 50, n. 4, p. 1778 - 1787, out/dez 2020. 


\section{ACKNOWLEDGMENTS}

We thank the Chico Mendes Institute for Biodiversity Conservation /ICMBio for providing the study area, the Amata company for logistical support and the Coordenação de Aperfeiçoamento de Pessoal de Nível Superior (CAPES) for the research grant.

\section{REFERENCES}

ALVARES, C. A.; STAPE, J. L.; SENTELHAS, P. C.; DE MORAES, G.; LEONARDO, J.; SPAROVEK; G. Köppen's climate classification map for Brazil. Meteorologische Zeitschrift, v. 22, n. 6, 2013.

AMATA. Plano Operacional Anual 05 UMF III. Amata S.A., São Paulo, SP. 2014.

BRASIL. Conselho Nacional do Meio Ambiente (CONAMA). Resolução CONAMA N. 01, de 23 de janeiro de 1986. Dispõe sobre critérios básicos e diretrizes gerais para a avaliação de impacto ambiental. Diário Oficial [da] República Federativa do Brasil, Brasília, DF, 17 de fev. de 1986. Disponível em:

<http://www2.mma.gov.br/port/conama/legislacao/CONAMA_RES_CONS_1986_001.pdf>.Acesso em: 01 jan. 2020.

BRASIL. Lei Federal n 9.985 de 18 de Julho de 2000. Regulamenta o art. 225, § 1o, incisos I, II, III e VII da Constituição Federal, institui o Sistema Nacional de Unidades de Conservação da Natureza e dá outras providências. Diário Oficial [da] República Federativa do Brasil, Brasília, DF, 18 de jul. 2000. Disponível em: <http://www.planalto.gov.br/ccivil_03/leis/19985.htm\#: :text=L9985\&text=LEI\%20No\%209.985\%2C\%20DE\% 2018\%20DE\%20JULHO\%20DE\%202000.\&text=Regulamenta\%20o\%20art.,Natureza\%20e\%20d\%C3\%A1\%2 0outras\%20provid\%C3\%AAncias.>. Acesso em: 01 jan. 2020.

BRASIL. Instrução Normativa n. 5, de 11 de dezembro de 2006. Dispõe sobre procedimentos técnicos para elaboração, apresentação, execução e avaliação técnica de Planos de Manejo Florestal Sustentável-PMFS nas florestas primitivas e suas formas de sucessão na Amazônia Legal. Diário Oficial [da] República Federativa do Brasil, Brasília, DF, 11 de dez. $2006 . \quad$ Disponível em: <https://www.mma.gov.br/estruturas/sfb/_arquivos/in05_manejo_florestal.pdf>. Acesso em: 01 jan. 2020.

GATTI, R. C.; CASTALDI, S.; COOMES, D. A.; MARCHETTI, M.; MAESANO, M.; DI PAOLA, A.; PAPARELLA, F.; VALENTINI, R. The impact of selective logging and clearcutting on forest structure, tree diversity and above-ground biomass of African tropical forests. Ecological research, v. 30, n. 1, p. 119 - 132 , 2015.

HIGUCHI, N.; SANTOS, J.; LIMA, A. J. N.; HIGUCHI, F. G.; SILVA, R. P.; SOUZA, C. A. S.; PINTO, F. R.; TEIXEIRA, L. M.; CARNEIRO, V. M. C.; SILVA, S. R. Perspectivas do manejo florestal sustentável para a Amazônia brasileira. Hiléia - Revista do Direito Ambiental da Amazônia, Manaus, n. 8, p. 78 - 93, 2010.

LIMA, B. de A.; Almeida, B. R. S. de; Sousa, E. A. B. de; Cruz, G. da S.; Melo, M. B.; Melo, L. de O.; Costa, D. L. da; Santos, M. F. dos. Estrutura e dinâmica florestal sob efeito do manejo madeireiro na FLONA Tapajós. Advances in Forestry Science, Cuiabá, v. 5, n. 4, p. 437 - 443, 2018.

LORENZI, H. Árvores Brasileiras: Manual de identificação e Cultivo de Plantas Arbóreas Nativas do Brasil. Nova Odessa SP: Instituto Plantarum, v. 2, 2002a.

LORENZI, H. Árvores Brasileiras: Manual de identificação e Cultivo de Plantas Arbóreas Nativas do Brasil. Nova Odessa SP: Instituto Plantarum, v. 2, 2002 b.

MAGRACH, A.; SENIOR, R. A.; ROGERS, A.; NURDIN, D.; BENEDICK, S.; LAURANCE, W. F.; SANTAMARIA, L.; EDWARDS, D. P. Selective logging in tropical forests decreases the robustness of lianatree interaction networks to the loss of host tree species. Proceedings of the Royal Society B: Biological Sciences, v. 283, n. 1826, p. 20153008, 2016.

MMA. Ministério do Meio Ambiente. Plano de manejo da Floresta Nacional do Jamari-Rondônia. Disponível em: <http://www.icmbio.gov.br/portal/images/stories/docs-planos-demanejo/flona_jamari_pm_diagnostico.pdf>. Brasília. 2005.

PUIG, H. Floresta tropical úmida: São Paulo: UNESP, 2008.

R CORE TEAM. R: A language and environment for statisticalcomputing. R Foundation for Statistical Computing, Vienna, Austria. 2019. URL https://www.R-project.org/. 
REIS, L. P.; RUSCHEL, A. R.; COELHO, A. A.; DA LUZ, A. S.; MARTINS-DA-SILVA, R. C. V. Avaliação do potencial madeireiro na Floresta Nacional do Tapajós, após 28 anos de exploração florestal. Pesquisa Florestal Brasileira, v. 30, n. 64, p. 265- 281, 2010.

SILVA, J. N. M.; LOPES, J. C. A.; OLIVEIRA, L. C.; SILVA, S. M. A.; CARVALHO, J. O. P.; COSTA, D. H. M.; MELO, M. S.; TAVARES, M. J. M. Diretrizes para instalação e medição de parcelas permanentes em florestas naturais da Amazônia Brasileira. Embrapa Amazônia Oriental, Belém, PA, 2005.

SOUZA, A. L., SOARES, C. P. B. Florestas Nativas: estrutura, dinâmica e manejo. Viçosa, MG. Ed. UFV. 2013.

SOUZA, D. R.; SOUZA, A. L. Estratificação vertical em floresta ombrófila densa de terra firme não explorada, Amazônia Oriental. R. Árvore, v. 28, n. 5, p. 691 - 698, 2004.

SOUZA, M. S.; AZEVEDO, C. P.; SOUZA, C. R.; FRANÇA, M.; NETO, E. L. V. Dinâmica e produção de uma floresta sob regime de manejo sustentável na Amazônia central. Floresta, v. 47, n. 1, p. 55 - 64, 2017.

VALERIANO, D. M.; ESCADA, M. I. S.; CÂMARA, G.; AMARAL, S.; MAURANO, L. E.; RENNÓ, C. D.; ALMEIDA, C. A.; MONTEIRO, A. M. V. O monitoramento do desmatamento. In: GEORGE M. População e Sustentabilidade na era das mudanças ambientais globais. ABEP. 2012.

VERÍSSIMO, A.; BARRETO, P.; MATTOS, M.; TARIFA, R.; UHL, C. Impactos da atividade madeireira e perspectivas para o manejo sustentável da floresta numa velha fronteira da Amazônia: o caso de Paragominas. A Expansão Madeireira na Amazônia, 2002.

VIDAL, E.; VIANA, V. M.; BATISTA, J. L. F. Crescimento de floresta tropical três anos após colheita de madeira com e sem manejo florestal na Amazônia oriental. Scientia Forestalis, v. 1, n. 61, p. 133 - $143,2002$.

VIEIRA, D. S.; GAMA, J. R. V.; OLIVEIRA, M. L. R.; RIBEIRO, R. B. S. Análise estrutural e uso múltiplo de espécies arbóreas em florestas manejadas no médio vale do Rio Curuá-Una, Pará. Floresta, v. 45, n. 3 , p. 465 476, 2015. 